\title{
The effects of armed conflict on schooling in Sub-Saharan Africa
}

\author{
Version 2
}

\begin{abstract}
In the past decades, most of the countries in Sub-Saharan Africa have been affected by armed conflicts. By means of a time-series cross-sectional (TSCS) database, we attempt to measure the impact of war on a sample of 43 countries in Africa from 1950 to 2010. These conflicts, and especially civil wars, are shown to have a strong negative effect on the educational performances of the countries studied. The rate of children not attending school, as well as secondary school enrollment rates, seems particularly sensitive to periods of conflict. It also appears that government expenditures in social sectors including education are a positive factor in increasing school enrollment. In contrast, military expenditure is significantly and inversely related to schooling opportunities. Thus, if an extra $1 \%$ only of the GDP were allocated to education expenditure, the rate of children not attending school would decrease by $1.7 \%$, the primary and secondary completion rates would increase respectively by $4.4 \%$ and by $2.6 \%$. The gender analysis shows that education expenditures provide a better retention of girls in the school system.
\end{abstract}

\section{Résumé}

Au cours de ces dernières décennies, la plupart des pays d'Afrique subsaharienne ont connu au moins un conflit armé. Cette étude présente des résultats préliminaires sur l'impact de ces conflits sur l'éducation entre 1950 et 2010 sur un panel de 43 pays d'Afrique. Les conflits et plus spécialement les guerres civiles ont un effet négatif très fort sur les performances éducatives des pays. Les non scolarisation et le secondaire paraissent particulièrement sensibles aux périodes de conflit. Il apparait également que les dépenses gouvernementales dans les secteurs sociaux et notamment en éducation sont un facteur favorable à l'augmentation des taux de scolarisation. A contrario, les dépenses militaires diminuent de façon significative les chances de scolarisation. Ainsi, si seulement $1 \%$ du PIB était alloué en direction de l'éducation, le taux de non scolarisation diminuerait de 1,7\% tandis que le taux de scolarisation secondaire augmenterait de 2,2\%.L'analyse du genre montre que les dépenses d'éducation permettent une meilleure rétention des filles à l'école.

Key words: Armed conflict, Education, Gender analysis, Sub-Saharan Africa JEL Codes: C32; H52; I22

\footnotetext{
${ }^{1}$ Corresponding author at: IREDU, Pôle AAFE, Esplanade Erasme, B.P. 26513, 21065 Dijon Cedex - France. Tel.: +33 (0)3 803937 41. Fax.: +33 (0)3 80395479 .

E-mail address : thomas.poirier@u-bourgogne.fr
} 


\section{Introduction}

Armed conflicts cause major damage and bring with them devastating consequences for a country, including casualties, displacement of populations, and the destruction of public infrastructure. In the long term, it appears to be very difficult to re-establish peace after a period of conflict. A World Bank report (2003) showed that the economic and social costs of wars are high and that they persist for years after the end of the conflict. In recent years, there has developed a substantial literature in which researchers debate the long-term negative consequences of armed conflicts. For instance, Brakman, Garretsen and Schramm (2004) show that the Allied bombing had a significant but temporary impact on post-war city growth in Germany as a whole, as well as in West Germany separately (although this is not the case for city growth in East Germany). Most studies arrive at similar conclusions. Miguel and Roland (2006) present evidence drawn from the American bombing in Vietnam. They find that war had no lasting impact on poverty rates, consumptions levels, literacy, infrastructure or population density. Chen, Loayza and Reynal-Querol (2007) analyze a panel of 41 countries involved in internal wars during the period 1960-2003 and find that when the end of war marks the beginning of lasting peace, recovery and improvement in economic performance, health, education and political development are indeed significant.

In the last decades, almost three-fourths of all countries in Sub-Saharan Africa (SSA) have been affected by armed conflicts (Gleditsch et al., 2002). Situations of conflict are often considered to be one of the most important factors in the deterioration of education. For example, Akresh and de Walque (2008) demonstrate the strong negative impact of Rwanda's genocide on children's schooling, with exposed children completing one-half year less education, resulting in an $18.3 \%$ decline in school completion. In the first place, children are often the first victims of wars: Bird (2007) underlines that two million children have died in the past decade as a consequence of armed conflict within the SSA region, and six million more have been injured or permanently disabled. In addition, as O'Malley (2010) points out, education, as one of the more visible institutions in the civil society, is often targeted by the belligerent parties in countries affected by military conflict. In many cases, an attack on the educational system represents an attack on the state. Conversely, certain states or paramilitary organizations may target academics in order to neutralize real or imagined opponents. In some contexts, there is also a phenomenon of youth recruitment into armed militias (child soldiers). 
The displacements caused by wars also prevent children's enrollment in school. In 2009, 27 million people worldwide were displaced, including 11.6 million people in 21 African countries (IDMC, 2010). Evidently, such events entail more drastic effects in Africa, as some countries in the region have education participation indicators which are among the lowest in the world. In 2007, in SSA, the Net Enrollment Rate (NER) was approximately 72\% (UNESCO, 2010). Some countries, like Eritrea or Niger, did not even reach the $50 \%$ level. On average, the literacy rate in SSA was measured at $60 \%$, but in Chad or Sierra Leone, it did not exceed $40 \%$ of the total population. In the same year, 72 million children worldwide were not attending school, of whom 32 million lived in SSA. Since the beginning of the 2000's, and in spite of the fact that African countries have expanded primary enrollments, rapidly developing current trends have illustrated a probable failure to reach Universal Primary Education (UPE) for 2015 (Easterly, 2009).

Given this context, the objective of this study is to present preliminary results on the effects of war on education in a broad sample of countries in the SSA region. The question is: to what extent is school enrollment impacted by armed conflicts? We assume that wars have a negative impact on schooling. However, this assumption raises certain issues: do all conflicts, whether civil, interstate or international, have the same effects? Are the consequences uniform whatever the intensity and duration of the conflict? Are both girls and boys affected equally by conflict? By means of a time-series cross-sectional (TSCS) database, we attempt to measure the impact of war on a sample of 43 countries in SSA from 1950 to 2010. We gathered information on conflict from the Peace Research Institute (PRIO) and indicators of civil liberties and political rights from the Freedom House. We then combined educational data from the Barro \& Lee database and economic data from the Penn World and the World Bank’s World Development Indicators.

\section{Data and methodology}

Our analysis focuses on Sub-Saharan African countries. The African continent includes a majority of countries which, in respect to current trends concerning the goal of universal education, will not, in all likelihood, achieve the objectives of Education for All (EFA) by 2015 (UNESCO, 2010). In addition, most of the countries in SSA have been affected by 
armed conflicts. Thus, 43 Sub-Saharan countries compose our sample of countries (for a list of countries with country codes, see Appendix A).

When studying these countries over time, the main obstacle we face is the lack of data and the reliability of that which is available. In this study, we rely on a number of databases known for their rigor and relevance. We have thus built from several databases a panel database for the period of time from 1950 to 2010 providing information on:

- Armed conflict;

- Education;

- Economic situation;

- Civil liberties and political rights.

A detailed description of our variables, including definitions and sources, is provided in Appendix B.

The information on conflicts is provided by the Armed Conflict Dataset of the International Peace Research Institute, Oslo (PRIO) ${ }^{1}$. This database, version 4-2009, identifies the number of conflicts for 142 countries from 1946 to 2008. Our panel of countries, each one providing an observation, consists of 42 countries (excluding Sao-Tome-and-Principe). The data document the conflicts for each country according to four dimensions:

- Territorial armed conflict between a state and a non-state group outside its own territory;

- Interstate armed conflict between two or more states;

- Internal armed conflict between the government of a state and one or more internal opposition group(s) without intervention from others states;

- Internationalized internal armed conflict between the government of a state and one or more internal opposition group(s) with intervention from others states on one or both sides.

\footnotetext{
${ }^{1}$ UCDP/PRIO Armed conflict dataset, version 4-2009. Available at http://www.prio.no/ (accessed on 07/12/2010).
} 
The data also characterize the conflicts in respect to their level of intensity. The viewpoint here is largely dichotomist: at between 25 and 999 battle-related deaths in a given year, a conflict is considered as minor. A minimum of 1,000 battle-related deaths in a given year qualifies the conflict as major.

Over the observed sixty year period, we find that $80 \%$ of the countries in our sample were engaged in at least one conflict (Appendix C). Only eight countries out of the 43 have never been involved in any kind of conflict, either internal or multistate: Benin, Botswana, Malawi, Namibia, Sao-Tome-and-Principe, Swaziland, Togo and Zambia. Some countries have faced several conflicts in the course of the same year. Angola and Ethiopia hold the unfortunate first place in terms of war in recent decades. Over the 60 years observed, both countries have experienced only 16 years without war and Ethiopia has faced up to five conflicts during the same sub period.

The education data comes from the recently updated data set on educational attainment in the world established by Barro and Lee ${ }^{2}$. This panel data set was updated in 2010 for 146 countries, including 33 Sub-Saharan countries. The data show the distribution of the educational attainment of the total adult population and of the adult population over the ages of 15,20 and 25 by sex at seven levels of schooling. For each level of education (primary, secondary, tertiary), data provide information on participation rates as well as completion rates. The rate of children not attending school is also documented. As part of our analysis, we particularly focus on children not enrolled in school and on primary school achievement. The data are broken down into 5-year intervals, from 1950 to 2010. In our analysis, these data have been annualized.

In one main component of our analysis, we use economic data provided by the Penn World Table ${ }^{3}$. This database, composed of 35 variables, displays a set of national accounts covering a spatial dimension of 189 countries, and the period 1950-2007 (with 2005 as base year) as time reference. For the needs of our study, we collected data concerning GDP per capita and investment share of real GDP per capita from 27 countries in SSA. Most data are available from 1960. We also selected some complementary economic data provided by the

\footnotetext{
${ }^{2}$ Barro, R.J., Lee, J.W., 2010. A new data set of educational attainment in the world, 1950-2010. National Bureau of Economics Research Working Paper 15902. Available at http://www.barrolee.com/ (accessed on 07/12/2010).

${ }^{3}$ Alan Heston, Robert Summers and Bettina Aten, Penn World Table Version 6.3, Center for International Comparisons of Production, Income and Prices at the University of Pennsylvania, August 2009. http://pwt.econ.upenn.edu/ (accessed on 07/12/2010).
} 
World Bank's World Development Indicators ${ }^{4}$. These data concern the total spending on education (in \% of GDP), military expenditure (in \% of GDP) and the general government final consumption expenditure (in \% of GDP). Because these data are more accurate than the previously mentioned set, it will be interesting to analyze them in the light of our hypotheses.

Finally, we added to our database the set of comparative and historical data established by the Freedom House in the World ${ }^{5}$. These data are the standard-setting comparative assessments of global political rights and civil liberties. Published annually since 1972, the survey ratings and narrative reports concern 193 countries and 15 related and disputed territories, including all the countries in our sample. The score indicated in the database is the average of the separate scores for civil liberties and political rights. In the Freedom House ranking, countries whose combined average for political rights and civil liberties fell between 1.0 and 3.0 (i.e., 1.0 $\leq$ avg_pr_cl<3.0) were designated "free"; between 3.0 and 5.5 (i.e.,

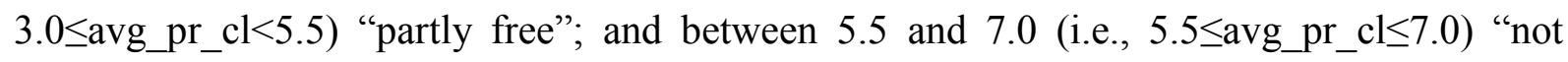
free".

The empirical analysis explores the behavior patterns of education variables during periods of armed conflict. Using TSCS data ${ }^{6}$, we test the impact of various economic, social and political variables on education variables. In this context, we preferred a simple method of fixed-effects (FE) regression, one for each SSA country. This provides a first evaluation of the effects of armed conflict by estimation through Ordinary Least Squares (OLS). The panel literature includes extensive debate about how to model effects, and in particular, whether we should treat them as fixed or random. For TSCS data, fixed effects are a more appropriate choice, whereas random effects are used for panel data (Beck, 2001).

The fixed-effect regression can be modeled as follows:

$$
\begin{aligned}
& Y_{i, t}=\alpha_{i}+\beta X_{i, t}+\mu_{i, t} \\
& \mu_{i, t}=\alpha_{i}+\epsilon_{i t}
\end{aligned}
$$

Where $Y_{i t}$ is the dependant variable observed for individual $i$ at time $t ; \alpha_{i}$ is the unobserved individual effect, $\beta$ the parameter of interest and $\mu_{i, t}$ the error term.

\footnotetext{
${ }^{4}$ Available at http://databank.worldbank.org/ddp/home.do (accessed on 07/12/2010).

${ }^{5}$ Available at http://www.freedomhouse.org/template.cfm?page $=1$ (accessed on 07/12/2010).

${ }^{6}$ A database is a TSCS when: $\mathrm{T}>1, \mathrm{~N}>1$ and $\mathrm{N}<\mathrm{T}$.
} 


\section{Results}

Adopting this causal framework in the statistical modeling that follows ${ }^{7}$, we selected three educational variables: the rate of children not attending school, the primary school completion rate and the secondary education enrollment rate. As part of our preliminary results, we chose to limit the explanatory variables. In terms of the variables of conflict, preliminary tests revealed that the variable "internal armed conflict" was more significant than the other three variables of conflict (territorial armed conflict, interstate armed conflict and internationalized armed conflict). It therefore seemed interesting to aggregate the latter into a single variable (called "Other conflict" in our models) and compare it to the first variable of conflict (called "Civil conflict" in our models). To appreciate the effect of conflict on education, we also selected the variable "intensity".

In terms of economic variables, we chose the GDP per capita, the investment share of real GDP per capita, the military and education expenditures, both also defined as a share of GDP. In order to take diffusion effects into account, these economic variables were lagged for five years in the models (indicated "L5" below).

As for the approach we selected to treat the data in a panel reference, it seemed meaningful to broadly decompose the variety of sources in search of that which is endogenous. When analyzing primary education completion rate, the average correlation within countries reaches a level of 0.64 ; on the other hand, correlation within years over the entire period studied reaches a level of 0.06. Respective values for the rate of children not attending school are 0.57 and 0.34 and 0.44 and 0.32 for the rate of secondary enrollment. In this way, spatial dispersions outbalance dispersion due to dynamic effects, particularly in the case of the primary completion rate.

\footnotetext{
${ }^{7}$ For our empirical analysis, we used the software Stata, version 11.0.
} 
Table 1

Fixed-effect regression (robust), Rate of children not in school (15 years and over).

\begin{tabular}{|c|c|c|c|c|}
\hline \multirow{2}{*}{$\begin{array}{l}\text { Dependant variable: } \\
\text { Rate of children not } \\
\text { in school }\end{array}$} & \multirow{2}{*}{ Explanatory variables } & \multicolumn{3}{|c|}{ Coefficients } \\
\hline & & Total & Girls & Boys \\
\hline & Civil conflict & $\begin{array}{c}4.247 * * * \\
{[1.499]}\end{array}$ & $\begin{array}{c}4.75 * * * \\
{[1.696]}\end{array}$ & $\begin{array}{c}3.748 * * * \\
{[1.40]}\end{array}$ \\
\hline & Other conflicts & $\begin{array}{c}2.965 * * \\
{[1.365]}\end{array}$ & $\begin{array}{l}2.769^{*} \\
{[1.538]}\end{array}$ & $\begin{array}{c}3.158 * * * \\
{[1.268]}\end{array}$ \\
\hline & Intensity & $\begin{array}{c}-1.519 \\
{[0.951]}\end{array}$ & $\begin{array}{c}-1.39 \\
{[1.131]}\end{array}$ & $\begin{array}{c}-1.646 * * \\
{[0.852]}\end{array}$ \\
\hline & GDP per capita (L5) & $\begin{array}{c}-0.002 * * * \\
{[0.000]}\end{array}$ & $\begin{array}{c}-0.002 * * * \\
{[0.000]}\end{array}$ & $\begin{array}{c}-0.002 * * * \\
{[0.000]}\end{array}$ \\
\hline & Investment share of real GDP (L5) & $\begin{array}{c}-0.138 * * \\
{[0.658]}\end{array}$ & $\begin{array}{c}-0.132 * * \\
{[0.061]}\end{array}$ & $\begin{array}{c}-0.143 * * \\
{[0.721]}\end{array}$ \\
\hline & Military expenditures (L5) & $\begin{array}{c}0.323 * * * \\
{[0.941)}\end{array}$ & $\begin{array}{c}0.284 * * * \\
{[0.917]}\end{array}$ & $\begin{array}{c}0.362 * * * \\
{[0.994]}\end{array}$ \\
\hline & Education expenditures (L5) & $\begin{array}{c}-0.638 * * * \\
{[0.186]}\end{array}$ & $\begin{array}{c}-0.371 * * \\
{[0.187]}\end{array}$ & $\begin{array}{c}-0.903 * * * \\
{[0.201]}\end{array}$ \\
\hline & Constant & $48.230 * * *$ & $53.522 * * *$ & $42.991 * * *$ \\
\hline & Adjusted R-Squared & 0.9746 & 0.978 & 0.968 \\
\hline & Observations/countries & $429 / 28$ & $429 / 28$ & $429 / 28$ \\
\hline
\end{tabular}

Notes: Robust standard errors in brackets; *significant at 10\%, **significant at 5\%, ***significant at $1 \%$.

In this model (Table 1), we find that the variables of conflict have a positive and significant effect on the rate of children not attending school. The assumption that conflicts increase the non enrollment rate is thus verified in the first model, and this impact is similar both for boys and girls. Military expenditures, which generally increase during a conflict, also have a positive and significant effect.

In contrast, the variables "education expenditures" and "investment share" have a negative effect. They thus act to reduce the proportion of children not attending school. The GDP is also significant although its coefficient is low compared to the other two variables.

Finally, the variable "intensity", describing the severity of a conflict, has a negative but not significant effect in terms of usual confidence levels, except for boys. 
In light of these initial results, it is interesting to analyze the average marginal effects by computing the elasticity effect of the explanatory variables. By means of this procedure ${ }^{8}$, we pose the following quantitative question: how much would our dependent variable increase if the independent variable had increased by $1 \%$ five years ago?

\section{Table 2}

Average marginal effects (robust).

\begin{tabular}{llccc}
\hline $\begin{array}{l}\text { Dependant variable: } \\
\text { Rate of Children not in } \\
\text { school }\end{array}$ & Explanatory variable & \multicolumn{3}{c}{ Coefficients } \\
\hline & & Total & Girls & Boys \\
\hline & \multirow{2}{*}{ Education expenditures (L5) } & $-0.017 * * *$ & $-0.008^{* *}$ & $-0.030^{* * *}$ \\
& & {$[0.004]$} & {$[0.004]$} & {$[0.007]$} \\
& Military Expenditures (L5) & $0.008^{* * *}$ & $0.006 * * *$ & $0.012^{* * *}$ \\
& & {$[0.002]$} & {$[0.002]$} & {$[0.003]$} \\
\hline Observations & 429 & & & \\
\hline
\end{tabular}

Notes: Robust standard errors in brackets; *significant at 10\%, **significant at 5\%, ***significant at $1 \%$.

Based on these results, we can say that if education expenditures had increased by $1 \%$ five years ago, the rate of children not attending school would have decreased by $1.7 \%$. Conversely, if military expenditures had increased by $1 \%$, the rate of children not in school would have increased by $0.8 \%$. The disparity between girls and boys is more significant. Indeed, the rate of boys not attending school would decreased by $3 \%$ and the rate of girls by "only" $0.8 \%$. Thus, spending on education would be first allocated to boys in early grades. In other words, demand of education within families gives advantage for boys.

\footnotetext{
${ }^{8}$ In terms of techniques, our results were obtained using the $\mathrm{mfx}$ command in the Stata statistical package.
} 
Table 3

Fixed-effect regression (robust), Primary education completion rate (15 years and over).

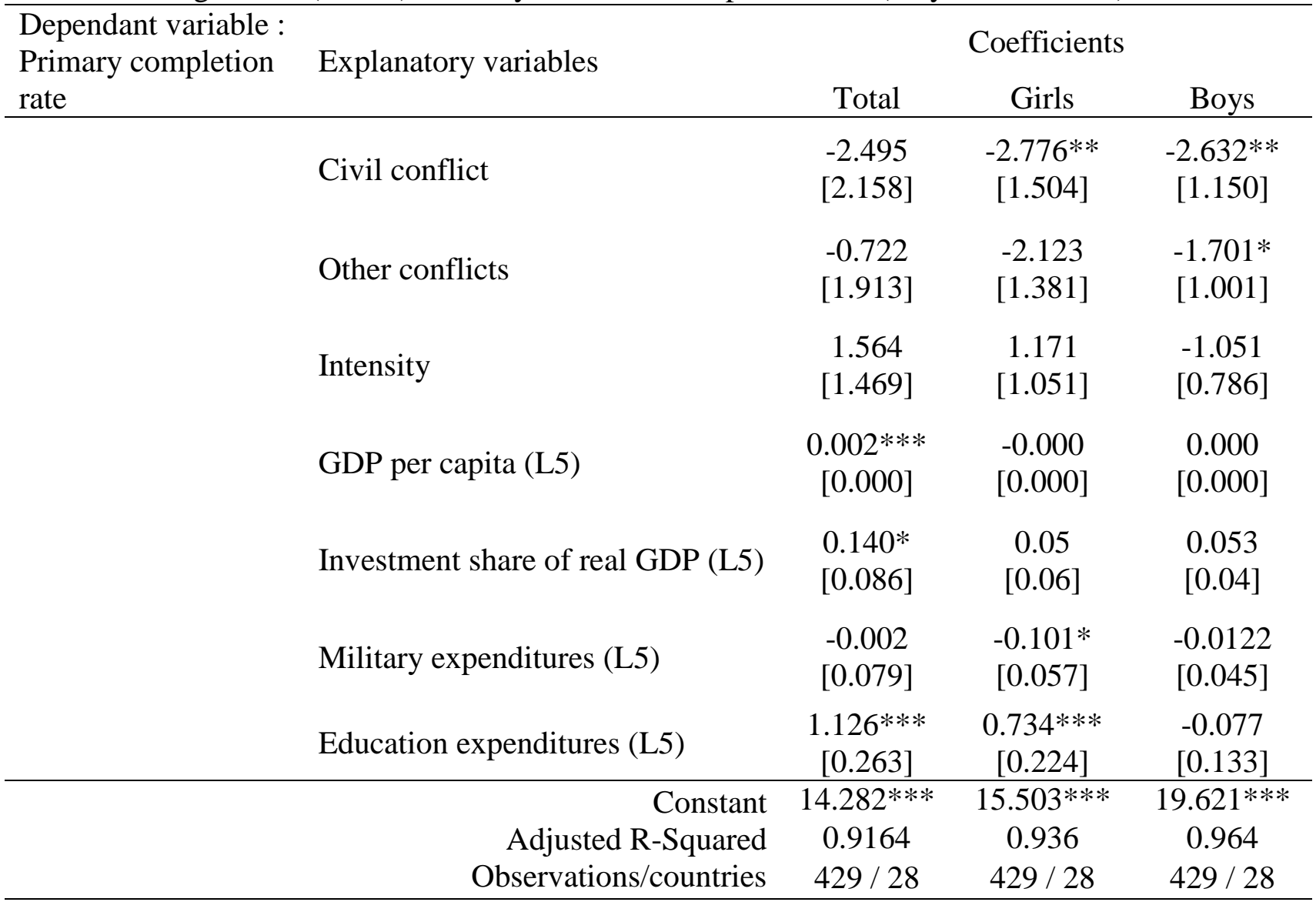

Notes: Robust standard errors in brackets; *significant at 10\%, **significant at 5\%, ***significant at $1 \%$.

In this model (Table 3), the variables "civil conflict", "other conflicts" and "military expenditures" have a negative effect on the primary school completion rate, as well as for girls than for boys. This trend may justify our assumptions although these variables are not always significant.

On the other hand, other economic variables have a positive and significant effect. We can say that social spending, particularly that targeted to education ("education expenditures"), increases the primary school completion rate, particularly for girls. This is verified by the average marginal effects (as for the first mode, Table 1): 


\section{Table 4}

Average marginals effects (robust).

\begin{tabular}{llccc}
\hline $\begin{array}{l}\text { Dependant variable: } \\
\text { Primary completion rate }\end{array}$ & Explanatory variable & \multicolumn{3}{c}{ Coefficients } \\
& & Total & Girls & Boys \\
\hline & \multirow{2}{*}{ Education expenditures (L5) } & $0.044^{* * *}$ & $0.039^{* * *}$ & 0.003 \\
& & {$[0.001]$} & {$[0.012]$} & {$[0.006]$} \\
& Military Expenditures (L5) & -0.000 & $-0.005 *$ & -0.000 \\
& & {$[0.003]$} & {$[0.003]$} & {$[0.002]$} \\
\hline Observations & 429 & &
\end{tabular}

Notes: Robust standard errors in brackets; *significant at 10\%, **significant at 5\%, ***significant at $1 \%$.

In a general way, primary completion rate would have increased by $4.4 \%$ if education expenditures had increased by $1 \%$ five years ago. Unlike the case of children not attending school, girls here benefit more than boys of education spending. Indeed, if education expenditures had increased by $1 \%$, girls receive a $3.9 \%$ for primary completion rate. Results show that this additional expenditure has no significant effect for boys in respect with the data we used. 


\section{Table 5}

Fixed-effect regression (robust), Secondary education enrollment rate (total, 15 years and over).

\begin{tabular}{|c|c|c|c|c|}
\hline \multirow{2}{*}{$\begin{array}{l}\text { Dependant variable : } \\
\text { Secondary enrollment } \\
\text { rate }\end{array}$} & \multirow{2}{*}{ Explanatory variables } & \multicolumn{3}{|c|}{ Coefficients } \\
\hline & & Total & Girls & Boys \\
\hline & Civil conflict & $\begin{array}{c}-2.271 * * \\
{[1.053]}\end{array}$ & $\begin{array}{c}-2.205^{* *} \\
{[1.011]}\end{array}$ & $\begin{array}{c}-2.337^{* *} \\
{[1.113]}\end{array}$ \\
\hline & Other conflicts & $\begin{array}{c}-2.137 * * \\
{[0.923]}\end{array}$ & $\begin{array}{c}-2.185^{* * * *} \\
{[1.381]}\end{array}$ & $\begin{array}{c}-2.089 * * \\
{[0.980]}\end{array}$ \\
\hline & Intensity & $\begin{array}{c}0.376 \\
{[0.799]}\end{array}$ & $\begin{array}{c}0.422 \\
{[0.767]}\end{array}$ & $\begin{array}{c}0.33 \\
{[0.844]}\end{array}$ \\
\hline & GDP per capita (L5) & $\begin{array}{c}0.004 * * * \\
{[0.000]}\end{array}$ & $\begin{array}{c}0.004 * * * \\
{[0.000]}\end{array}$ & $\begin{array}{c}0.004 * * * \\
{[0.000]}\end{array}$ \\
\hline & Investment share of real GDP (L5) & $\begin{array}{c}0.108 * * \\
{[0.045]}\end{array}$ & $\begin{array}{c}0.093 * * \\
{[0.041]}\end{array}$ & $\begin{array}{c}0.122 * * \\
{[0.05]}\end{array}$ \\
\hline & Military expenditures (L5) & $\begin{array}{c}-0.124 * * \\
{[0.061]}\end{array}$ & $\begin{array}{l}-0.088 \\
{[0.057]}\end{array}$ & $\begin{array}{c}-0.016 * * * \\
{[0.066]}\end{array}$ \\
\hline & Education expenditures (L5) & $\begin{array}{c}0.505 * * * \\
{[0.173]}\end{array}$ & $\begin{array}{c}0.44 * * * \\
{[0.180]}\end{array}$ & $\begin{array}{c}0.057 * * * \\
{[0.174]}\end{array}$ \\
\hline & Constant & $12.742 * * *$ & $8.933 * * *$ & $16.513^{* * *}$ \\
\hline & Adjusted R-Squared & 0.9765 & 0.975 & 0.977 \\
\hline & Observations/countries & $429 / 28$ & $429 / 28$ & $429 / 28$ \\
\hline
\end{tabular}

Notes: Robust standard errors in brackets; *significant at 10\%, **significant at 5\%, ***significant at $1 \%$.

Turning now to the secondary school enrollment rate (Table 5), our results are appealing. They confirm previous results. Conflicts and related expenditures (military expenditures) have a negative effect, while social spending has a positive one. In this model, and contrary to our findings concerning primary education (Table 3), coefficients are significant (except impact of military expenditures change for girls). Conflicts therefore have a very strong impact on secondary enrollment.

The average marginal effects are also interesting, particularly in gender analysis: 


\section{Table 6}

Average marginal effects (robust).

Dependant variable:

Secondary enrollment

rate

Explanatory variable

Coefficients

\begin{tabular}{cccc} 
& & & \\
Education expenditures (L5) & $0.022^{* * *}$ & $0.024 * * *$ & $0.021^{* * * *}$ \\
& {$[0.007]$} & {$[0.009]$} & {$[0.006]$} \\
& $-0.005^{* *}$ & -0.005 & $-0.006^{* * *}$ \\
Military Expenditures (L5) & {$[0.002]$} & {$[0.003]$} & {$[0.002]$} \\
\hline
\end{tabular}

Observations

429

Notes: Robust standard errors in brackets; *significant at 10\%, **significant at 5\%, ***significant at $1 \%$.

If we compare the marginal effects above to those computed for the rate of children not attending school (Table 2), we note that they are more pronounced in the case of the secondary enrollment rate. Indeed, if education expenditures had increased by $1 \%$ five years ago, secondary school enrollment would have increased by $2.2 \%$. If military expenditures had increased by $1 \%$, this rate would have decreased by $0.5 \%$. For girls, this increase is at level $2.4 \%$ against $2.1 \%$ for boys. As for primary completion rate, girls have more benefited from this increase. To check this trend, we conducted the same analysis on secondary school completion rate:

\section{Table 7}

Average marginals effects (robust)

\begin{tabular}{|c|c|c|c|c|}
\hline \multirow{2}{*}{$\begin{array}{l}\text { Dependant variable: } \\
\text { Secondary completion } \\
\text { rate }\end{array}$} & \multirow{2}{*}{ Explanatory variable } & \multicolumn{3}{|c|}{ Coefficients } \\
\hline & & Total & Girls & Boys \\
\hline & Education expenditures (L5) & $\begin{array}{c}0.026 * * * \\
{[0.009]}\end{array}$ & $\begin{array}{c}0.041 * * * \\
{[0.011]}\end{array}$ & $\begin{array}{l}0.016^{*} \\
{[0.009]}\end{array}$ \\
\hline & Military Expenditures (L5) & $\begin{array}{c}-0.006 \\
{[0.005]}\end{array}$ & $\begin{array}{c}-0.007 \\
{[0.006]}\end{array}$ & $\begin{array}{l}-0.006 \\
{[0.006]}\end{array}$ \\
\hline Observations & 429 & & & \\
\hline
\end{tabular}

Here, the difference between girls and boys is more significant. If education expenditures had increased by $1 \%$ five years ago, $4.1 \%$ more girls could reach completion for secondary against $1.6 \%$ for boys. 
The R-squared $\left(\mathrm{R}^{2}\right)$ in the models merits commentary. Indeed, its analysis reveals that the explanatory variables account for a large part of the variance in the models. In the analysis of our data by Stata, we had the choice between two main commands: xtreg, fe and areg. We chose the areg procedure. This command includes the robust option for the correction of heteroskedasticity in groups ${ }^{9}$ using White's method. In fact, the coefficient estimates and standard errors are the same using the xtreg, fe and areg procedures, but the calculation of the $\mathrm{R}^{2}$ is different. In the areg procedure, we estimate coefficients for each of our covariates and for each dummy variable in our groups. In the xtreg, fe procedure, the reported $\mathrm{R}^{2}$ is obtained simply by fitting a mean deviated model where the effects of the groups (all of the dummy variables corresponding to country cases) are assumed to be fixed quantities. All the group effects are simply subtracted out of the model and no attempt is made to quantify their overall effect on the fit of the model. The SSE (sum-of-squares-error) is the same regardless of which approach we take, but the SST (sum-of-squares total) is different. In the xtreg, fixed-effect approach, the $\mathrm{R}^{2}$ reported is not the $\mathrm{R}^{2}$ that is calculated from the regression for areg, but the regression for the mean detrended dataset. As such, the SST in the xtreg, fe approach is less than the SST in the areg approach. The difference is real. When adopting the xtreg, fe method, the effects of the groups are fixed and unestimated quantities which are subtracted out of the model before the fit is performed. In the areg approach, the group effects are estimated and affect the total sum of squares of the model under consideration. The examples below illustrate this point:

\footnotetext{
${ }^{9}$ Statistical phenomena which may be magnified in the present situation by the huge differences in the sizes of the countries in our sample.
} 


\section{Table 8}

Fixed-effect regression (robust), Rate of children not in school (15 years and over), comparison between areg and xtreg, fe commands (Stata).

\begin{tabular}{|c|c|c|c|c|}
\hline \multirow{2}{*}{$\begin{array}{l}\text { Dependant variable : } \\
\text { Rate of children not in } \\
\text { school }\end{array}$} & \multirow{2}{*}{\multicolumn{2}{|c|}{ Explanatory variables }} & \multicolumn{2}{|c|}{ Coefficients } \\
\hline & & & $\begin{array}{l}\text { Model } 1 \\
\text { (xtreg,fe) }\end{array}$ & $\begin{array}{c}\text { Model } 2 \\
\text { (areg) }\end{array}$ \\
\hline & \multicolumn{2}{|c|}{ Civil conflict } & $\begin{array}{c}4.246 * * * \\
{[1.623]}\end{array}$ & $\begin{array}{c}4.247 * * * \\
{[1.499]}\end{array}$ \\
\hline & \multicolumn{2}{|c|}{ Other conflicts } & $\begin{array}{c}2.964 \\
{[1.972]}\end{array}$ & $\begin{array}{c}2.965 * * \\
{[1.365]}\end{array}$ \\
\hline & \multicolumn{2}{|l|}{ Intensity } & $\begin{array}{c}-1.519 \\
{[1.293]}\end{array}$ & $\begin{array}{c}-1.519 \\
{[0.951]}\end{array}$ \\
\hline & \multicolumn{2}{|c|}{ GDP per capita (L5) } & $\begin{array}{c}-0.002 * * * \\
{[0.000]}\end{array}$ & $\begin{array}{c}-0.002 * * * \\
{[0.000]}\end{array}$ \\
\hline & \multicolumn{2}{|c|}{ Investment share of real GDP (L5) } & $\begin{array}{c}-0.138 * * * \\
{[0.487]}\end{array}$ & $\begin{array}{c}-0.138 * * \\
{[0.658]}\end{array}$ \\
\hline & \multicolumn{2}{|c|}{ Military expenditures (L5) } & $\begin{array}{c}0.323 * * * \\
{[0.884]}\end{array}$ & $\begin{array}{c}0.323 * * * \\
{[0.941]}\end{array}$ \\
\hline & \multicolumn{2}{|c|}{ Education expenditures (L5) } & $\begin{array}{c}-0.638^{* * * *} \\
{[0.196]}\end{array}$ & $\begin{array}{c}-0.638 * * * \\
{[0.186]}\end{array}$ \\
\hline & \multicolumn{2}{|c|}{ Constant } & $48.230 * * *$ & $48.230 * * *$ \\
\hline & \multicolumn{2}{|c|}{ Adjusted R-Squared } & - & 0.9746 \\
\hline & \multirow{3}{*}{ R-squared } & Within & 0.1616 & - \\
\hline & & Between & 0.3515 & - \\
\hline & & Overall & 0.3291 & - \\
\hline & \multicolumn{2}{|c|}{ Observations/countries } & $429 / 28$ & $429 / 28$ \\
\hline
\end{tabular}

Notes: Robust standard errors in brackets; *significant at 10\%, **significant at 5\%, ***significant at $1 \%$.

First, the comparison between the two models shows that the coefficients are identical, except for the variable "other conflicts".

Xtreg, fe computes three R-squared values. The " $\mathrm{R}^{2}$ within" gives the share of intraindividual variability of the dependent variable explained by the explanatory variables. The " $\mathrm{R}^{2}$ between" considers the contribution of the fixed effects to the model. The " $\mathrm{R}^{2}$ overall" reflects the overall quality of the regression.

In the example given above, we can say that variety within the country explains $16 \%$ of the variance in the model whereas variety between countries accounts for $35 \%$. 


\section{Table 9}

Fixed-effect regression (robust), Secondary enrollment rate (total, 15 years and over), comparison between areg and xtreg, fe commands (Stata).

\begin{tabular}{|c|c|c|c|c|}
\hline \multirow{2}{*}{$\begin{array}{l}\text { Dependant variable : } \\
\text { Secondary enrollment } \\
\text { rate }\end{array}$} & \multirow{2}{*}{\multicolumn{2}{|c|}{ Explanatory variables }} & \multicolumn{2}{|c|}{ Coefficients } \\
\hline & & & $\begin{array}{l}\text { Model } 1 \\
\text { (xtreg,fe) }\end{array}$ & $\begin{array}{l}\text { Model } 2 \\
\text { (areg) }\end{array}$ \\
\hline & \multicolumn{2}{|c|}{ Civil conflict } & $\begin{array}{c}-2.271 \\
{[1.304]}\end{array}$ & $\begin{array}{c}-2.271 * * \\
{[1.053]}\end{array}$ \\
\hline & \multicolumn{2}{|c|}{ Other conflicts } & $\begin{array}{c}-2.137 \\
{[1.583]}\end{array}$ & $\begin{array}{c}-2.137 * * \\
{[0.923]}\end{array}$ \\
\hline & \multicolumn{2}{|l|}{ Intensity } & $\begin{array}{c}0.376 \\
{[1.039]}\end{array}$ & $\begin{array}{c}0.376 \\
{[0.799]}\end{array}$ \\
\hline & \multicolumn{2}{|c|}{ GDP per capita (L5) } & $\begin{array}{c}-0.004 * * * \\
{[0.000]}\end{array}$ & $\begin{array}{c}0.004 * * * \\
{[0.000]}\end{array}$ \\
\hline & \multicolumn{2}{|c|}{ Investment share of real GDP (L5) } & $\begin{array}{c}-0.108 * * * \\
{[0.391]}\end{array}$ & $\begin{array}{l}0.108 * * \\
{[0.045]}\end{array}$ \\
\hline & \multicolumn{2}{|c|}{ Military expenditures (L5) } & $\begin{array}{c}-0.124 * * * \\
{[0.709]}\end{array}$ & $\begin{array}{c}-0.124 * * \\
{[0.061]}\end{array}$ \\
\hline & \multicolumn{2}{|c|}{ Education expenditures (L5) } & $\begin{array}{c}0.505 * * * \\
{[0.157]}\end{array}$ & $\begin{array}{c}0.505 * * * \\
{[0.173]}\end{array}$ \\
\hline & \multirow{2}{*}{\multicolumn{2}{|c|}{$\begin{array}{l}\text { Constant } \\
\text { Adjusted R-Squared }\end{array}$}} & $12.742 * * *$ & $12.742 * * *$ \\
\hline & & & - & 0.9765 \\
\hline & R-squared & $\begin{array}{l}\text { Within } \\
\text { Between } \\
\text { Overall }\end{array}$ & $\begin{array}{l}0.2385 \\
0.5265 \\
0.5613\end{array}$ & $\begin{array}{l}- \\
- \\
-\end{array}$ \\
\hline & \multicolumn{2}{|c|}{ Observations/countries } & $429 / 28$ & $429 / 28$ \\
\hline
\end{tabular}

Notes: Robust standard errors in brackets; *significant at 10\%, **significant at 5\%, ***significant at $1 \%$.

In Table 9, variety within the country explains $23 \%$ (" $\mathrm{R}^{2}$ within") of the variance in the model whereas variety between the countries accounts for $35 \%$ (" $\mathrm{R}^{2}$ between"). We note a difference in the variables of conflict. Indeed, the coefficients are similar but in model 1, they are not significant.

In both cases, we can conclude that variety is mainly explained by the difference between countries rather than by intra-individual variety.

Finally, we tested the Freedom House's indicators on the educational performances. Freedom House ranks countries in terms of political rights and civil liberties. Countries are classified according to various indicators which translate the situation in the country, at a 
particular observation date, for objectives that are derived to a large extent from the Universal Declaration of Human Rights. Obviously, these objectives are documented by means of factual events such as the transparency of political choice, liberty in the press and so on (reference to latest FH report). Countries are assessed as free, partly free, or not free in terms of political rights and civil liberties in accordance with the value attributed each year to each country for these two indicators. Each indicator is scaled from the value of 1, the best situation, to the value of 7 , the worst.

Our present hypothesis is based on the fact that these two indicators may be impacted by the population's participation in education. In fact, we must use extreme caution, as such a hypothesis is largely impossible to test without the expected spurious correlations and structural effects. One fractional issue might be to chart the evolution of both indicators in respect to three main explaining factors: the indicator of school participation, GDP per capita taken as a trend for economic development and the occurrence of a conflict during the 5 year span that preceded the observations.

In this case, we could adopt a panel approach, as the variation of indicators and variables is here largely heterogeneous within countries; we calculate panel-corrected standard error (PCSE) estimates for linear cross-sectional time series models where the parameters are estimated by either OLS or Prais-Winsten regression ${ }^{10}$. When computing the standard errors and the variance-covariance estimates, the procedure used assumes that the disturbances are, by default, heteroskedastic and contemporaneously correlated across panels. We did not use fixed effect dummies here, so the variety explained is low. Results concerning primary school achievement are to be rejected due to their lack of confidence. For other variables, the impact of past or present conflict shows a marginal value close to 0.5 for both the political rights and civil liberties scales. Despite its high significance, the marginal impact for the uneducated population at age 15 is low. A simulation of marginal impact, that is to say a decrease from the $20 \%$ level to the $10 \%$ level in this uneducated population, results in a decline of around 0.25 in both scales of political rights and civil liberties. Impact effects from change in secondary education are higher, as, for example, a move from $20 \%$ to $30 \%$ means a decline (more liberties) of around 0.30 in both scales of freedom potential.

\footnotetext{
${ }^{10}$ Using the xtpcse procedure in Stata.
} 
Table 10

Impact of no school at age 15, economic growth and conflicts on liberties and political rights.

\begin{tabular}{lccccc} 
Explained & GDP per capita & $\begin{array}{c}\text { No school at } \\
\text { age 15 }\end{array}$ & $\begin{array}{c}\text { Conflicts have } \\
\text { occurred in past 5 years }\end{array}$ & Constant & R2 \\
\hline Political rights & $-.0000872 * * *$ & $.0093729 * * *$ & $0.47249 * *$ & 5.12 & 0.1081 \\
Civil Liberties & $-.0088601 * * *$ & $.000126 * * *$ & $0.49647 * *$ & 4.54 & 0.071 \\
\hline
\end{tabular}

Notes: *significant at $10 \%, * *$ significant at $5 \%, * * *$ significant at $1 \%$.

Estimations included 824 observations sampled in 22 Sub-Saharan countries, from the period 1965 to 2007.

\section{Table 11}

Impact of participation in secondary schooling, economic growth and conflicts on liberties and political rights.

\begin{tabular}{lcccrc}
\hline Explained & GDP per capita & $\begin{array}{c}\text { Secondary } \\
\text { participation }\end{array}$ & $\begin{array}{c}\text { Conflicts have } \\
\text { occurred in past 5 years }\end{array}$ & Constant & R2 \\
\hline Political rights & $-.0000263 * * *$ & $-.019383 * * *$ & $0.39595 * *$ & 5.63 & 0.1513 \\
Civil Liberties & $-.000026 *$ & $-.020099 * * *$ & $0.417387 * *$ & 5.25 & 0.1032 \\
\hline
\end{tabular}

Notes: *significant at $10 \%, * *$ significant at $5 \%, * * *$ significant at $1 \%$.

Estimations included 824 observations sampled in 22 Sub-Saharan countries, from the period 1965 to 2007.

\section{Discussion}

These preliminary results confirm that armed conflicts have a strong negative impact on education. Indeed, results show that the rate of children not attending school as well as that of secondary school enrollment is very sensitive to conflicts (Tables 1 and 5). The model presented in Table 3 shows that the primary completion rate appears to be less affected. Nevertheless, as demonstrated in the cases of secondary school and children not in school, when the country's resources are allocated to education, they contribute significantly to improving school enrollments. Military expenditures have the opposite impact since school enrollments decrease under its effect. In a general way, the calculation of the average marginal effects (Tables 2, 4 and 7) demonstrates that the rate of children not attending school could decrease by $1.7 \%$, the primary and secondary completion rates would increase respectively by $4.4 \%$ and by $2.6 \%$ if an extra $1 \%$ only of the GDP were allocated to education expenditures. The secondary school enrollment rate would increase by $2.2 \%$ (Table 6). These findings 
indicate that a rise in education investment has two effects: on the one hand, the primary school completion rate increases; on the other hand, further study in secondary school also increases significantly. The discrimination between girls and boys is instructive. Education expenditures benefit first to boys (Tables 1 and 2). Certainly by choice inside families, boys are first enrolled in school rather than girls. Then, results show that along school career, these expenditures have more marginal effects on girls. Indeed, if an extra $1 \%$ only of the GDP were allocated to education expenditures, the completion rate of girls for primary would increase by $3.9 \%$ (Table 4). On the other hand, in secondary school, the enrollment rate would increase by $2.4 \%$ for girls against an increase at level $2.1 \%$ for boys (Table 6). The completion rate is more significant. Indeed, respectively for girls and boys, this rate could increase by $4.1 \%$ against $1.6 \%$ (Table 7 ). Thus, investment in education provides a better retention of girls in the school system, both in primary education and secondary education. Certainly, UPE is one of the goals of EFA, but several studies have highlighted the importance of secondary school. In a study of fragile states, Chauvet and Collier (2007) underline that one of the characteristics of these states is the relentless nature of their fragility and the lack of reforms. The introduction of reforms, including in particular a wealthier economy, is considered to be a necessary condition for the advancement of fragile states out of the category. Unfortunately, the econometric estimation of a state's likelihood of out of the fragile state category suggests that each year, the chances are less than $2 \%$ that a substantial impetus will begin. This implies that fragile states remain so an average of approximately 55 years. Chauvet and Collier identified factors which contribute to the emergence of a state from its fragile status: secondary education, population size, the gross income related to natural resources and technical assistance. A $1 \%$ increase in the number of those who have completed secondary education doubles the likelihood of the implementation of reforms, even if this condition has little impact on the progress of reform. In this way, the persistence of fragile status decreases from 55 to 37 years. Twenty-two countries in our sample are considered as fragile ${ }^{11}$ and $45 \%$ of the states involved in internal armed conflict relapse into armed conflict within five years (ibid). In fragile states, the risk of civil war may be attributed to two major factors: the proportion of young men in the population and the weakness of growth (Collier, Hoeffler and Rohner, 2006). Education may in fact have a double effect in

\footnotetext{
${ }^{11}$ In 2007, the World Bank listed 34 fragile states, including 22 Sub-Saharan countries.
} 
limiting the risks of war: at school, young men are busy and a long formal education increases their chances of employability. Thus, investment in education can reduce the risk of conflict, and our study corroborates previous results highlighting the importance of education in the peace process (Miller-Grandvaux, 2009). Education may therefore offer a way out of the "war trap" and, by extension, the poverty trap that some countries face. This positive framework is only sustainable if certain "returns on investment", such as the employability of youths, are obtained from success in formal schooling. Nevertheless, an increasing literature underlines the highly complex relationships between education and conflict. Bush and Saltarelli (2000) highlights how education has "two faces". In its positive face, as we have suggested, education can be a pathway to peace building. In the midst of a conflict, its maintenance is a means of socialisation and schools may provide an important mechanism for the protection of children against abuse (Smith and Vaux, 2003). In its negative face, education might be a catalyst for war. Indeed, it can be used as a war weapon in promoting intolerance, in excluding certain groups to access to school or in exacerbating ethnic tensions. In some countries, the exaltation of nationalism in the history books may result in the rise of xenophobia and violence (UNESCO, 1998). Through social exclusion and indoctrination, schools can be a vehicle of violence (Novelli and Lopez Cardozo, 2008) as in Rwanda where the educational system established since colonial period has favored political, economic and social domination of Tutsis on Hutus. Lastly, the decentralisation policies, especially in education, could lead to effects counterproductive and deteriorate further a present fragile situation (Altinok, 2004). Indeed, Châtaigner and Magro (2007), show that civil wars in poorer countries since the end of the Cold War and the early 1990's are grew out of the weakening of states "privatized". With the 9/11 events, these fragile states have become a strategic issue for the international development agencies. Rebuild the rule of law and strengthen institutions have become a priority. Nevertheless, there is no consensus on what the term "fragile states" encompass or exclude. Those working within education aid have adopted the terminology "fragile states" but this concept remains ambiguous and appears to have come about to fill a conceptual gap in the aid literature (Bengtsson, 2011). Fragile states, however, have one common characteristic: being or having been in conflict. But each situation is unique and the emergence of conflicts is a complex process in which education can be one of many causes inside a chicken or egg causality. 
So, investment in education is necessary but, this is not a sufficient condition. On the one hand, education must be protected from political interference and clientelism (Weber, 2009). On the other hand, educational development policies must be supported by a true and genuine political will, shared by all the stakeholders. If this is not the case, education may be viewed in its negative aspects, reinforcing the idea of the "education trap" as pointed out by Pritchett (2001).

\section{Conclusion}

This study discusses the negative impact of conflict on education. Our empirical analysis also indicates that social expenditures, especially expenditures in education, have a positive and very significant impact on the educational performance of our sample of countries. Military expenditures have the opposite effect. This trend indicates that when a country invests in the social sector, particularly in education, school enrollments increase significantly. This can also be interpreted as an indicator of government priorities. When a government gives priority to the social sector, it sends a signal to the population that lasting peace has returned, which in turn raises confidence in the civil peace needed to boost investment (Collier and Hoeffler, 2002). Education can then play a part to reduce poverty. Moreover, as suggested by Harber (2002), education can be also a vehicle of peace in helping to promote democracy. Even if education systems cannot be the exclusive solution to the problem of democratisation, it can contribute to cultivate and develop the values and behaviors of a democratic political system. Our analysis shows that education can play a role in the development of political rights and civil liberties. In addition, the occurrence of civil conflicts in Africa is intimately related to government expenditure policy and, thus, the failure of a government to commit to a strong redistributive towards social domains such as education (Azam, 2001). As we have analyzed, in the midst of a conflict, education can be a part of the solution as well it can be also a driver of conflict (Smith, 2010). In some countries, it is the school system itself that sows the seeds of war and conflict (Davies, 2005). It is also generally accepted that periods of peace are more conducive to investments in the social sector. Studies show that pre-conflict periods are often marked by increased military expenditures, at the expense of education and / or health. These preliminary results are part of a larger work that attempts to highlight the impact of fragility on education. Our findings lead 
us to raise certain questions for further study and analysis. Indeed, the primary school completion rate does not appear to be significantly affected by conflict, unlike the rate of children not attending school or that of secondary enrollment. According to our models, the intensity of the conflict does not appear to be a relevant factor in enrollment. These questions call for further, more in depth study to complete and complement this initial research. 
Appendix A: Countries and country codes

\begin{tabular}{|c|c|c|}
\hline & Country & Country code \\
\hline 1 & ANGOLA & $\mathrm{AO}$ \\
\hline 2 & BENIN & $\mathrm{BJ}$ \\
\hline 3 & BOTSWANA & BW \\
\hline 4 & BURKINA FASO & $\mathrm{BF}$ \\
\hline 5 & BURUNDI & BI \\
\hline 6 & CAMEROON & $\mathrm{CM}$ \\
\hline 7 & CENTRAL AFRICAN REPUBLIC & $\mathrm{CF}$ \\
\hline 8 & CHAD & TD \\
\hline 9 & CONGO & $\mathrm{CG}$ \\
\hline 10 & CONGO, THE DEMOCRATIC REPUBLIC OF THE & $\mathrm{CD}$ \\
\hline 11 & CÔTE D'IVOIRE & CI \\
\hline 12 & EQUATORIAL GUINEA & GQ \\
\hline 13 & ERITREA & ER \\
\hline 14 & ETHIOPIA & ET \\
\hline 15 & GABON & GA \\
\hline 16 & GAMBIA & GM \\
\hline 17 & GHANA & GH \\
\hline 18 & GUINEA & GN \\
\hline 19 & GUINEA-BISSAU & GW \\
\hline 20 & KENYA & $\mathrm{KE}$ \\
\hline 21 & LESOTHO & LS \\
\hline 22 & LIBERIA & LR \\
\hline 23 & MADAGASCAR & MG \\
\hline 24 & MALAWI & MW \\
\hline 25 & MALI & ML \\
\hline 26 & MAURITANIA & MR \\
\hline 27 & MOZAMBIQUE & $\mathrm{MZ}$ \\
\hline 28 & NAMIBIA & NA \\
\hline 29 & NIGER & $\mathrm{NE}$ \\
\hline 30 & NIGERIA & NG \\
\hline 31 & RWANDA & RW \\
\hline 32 & SAO TOME AND PRINCIPE & ST \\
\hline 33 & SENEGAL & SN \\
\hline 34 & SIERRA LEONE & SL \\
\hline 35 & SOMALIA & $\mathrm{SO}$ \\
\hline 36 & SOUTH AFRICA & $\mathrm{ZA}$ \\
\hline 37 & SUDAN & SD \\
\hline 38 & SWAZILAND & SZ \\
\hline 39 & TANZANIA, UNITED REPUBLIC OF & $\mathrm{TZ}$ \\
\hline 40 & TOGO & TG \\
\hline 41 & UGANDA & UG \\
\hline 42 & ZAMBIA & $\mathrm{ZM}$ \\
\hline 43 & ZIMBABWE & $\mathrm{ZW}$ \\
\hline
\end{tabular}

Source: International Organisation for Standardization 


\section{Appendix B: Definitions and sources of variables}

\begin{tabular}{|c|c|c|c|}
\hline Variables & Definition & \multicolumn{2}{|l|}{ Source } \\
\hline Some primary school & $\begin{array}{l}\text { Some primary school education (\% of population aged } \\
15,20 \text { or over } 25 \text { ) }\end{array}$ & Barro \& Lee dataset 201 & \\
\hline Primary school completed & $\begin{array}{l}\text { Primary school completed ( } \% \text { of population aged } 15,20 \\
\text { or over } 25 \text { ) }\end{array}$ & Barro \& Lee dataset 201 & \\
\hline Some secondary school & $\begin{array}{l}\text { Some secondary school education ( } \% \text { of population aged } \\
15,20 \text { or over } 25 \text { ) }\end{array}$ & Barro \& Lee dataset 201 & \\
\hline $\begin{array}{l}\text { Secondary school } \\
\text { completed }\end{array}$ & $\begin{array}{l}\text { Secondary school completed (\% of population aged } 15 \text {, } \\
20 \text { or over } 25 \text { ) }\end{array}$ & Barro \& Lee dataset 201 & \\
\hline Some higher education & $\begin{array}{l}\text { Some higher education undertaken ( } \% \text { of population aged } \\
15,20 \text { or over } 25 \text { ) }\end{array}$ & Barro \& Lee dataset 201 & \\
\hline Higher education completed & $\begin{array}{l}\text { Post-secondary school degree completed } \quad\left(\begin{array}{ll}\% & \text { of } \\
\text { population aged } 15,20 \text { or over } 25\end{array}\right)\end{array}$ & Barro \& Lee dataset 201 & \\
\hline Government expenditure & $\begin{array}{l}\text { General government final consumption expenditure (\% of } \\
\text { GDP) }\end{array}$ & $\begin{array}{l}\text { World Bank's } \\
\text { Development Indicators }\end{array}$ & World \\
\hline Military expenditure & $\begin{array}{l}\text { Military expenditure }(\% \text { of central government } \\
\text { expenditure })\end{array}$ & $\begin{array}{l}\text { World Bank's } \\
\text { Development Indicators }\end{array}$ & World \\
\hline Investment share & Investment share of real GDP per capita (unit \%) & Penn World Tables 6.3 & \\
\hline GDP per capita & Real GDP per capita, current price & Penn World Table 6.3 & \\
\hline Territorial conflict & $\begin{array}{l}\text { Armed conflict between a state and a non-state group } \\
\text { outside its own territory }\end{array}$ & $\begin{array}{l}\text { International Peace } \\
\text { Institute, Oslo (PRIO) }\end{array}$ & Research \\
\hline Interstate conflict & Armed conflict between two or more states & $\begin{array}{l}\text { International Peace } \\
\text { Institute, Oslo (PRIO) }\end{array}$ & Research \\
\hline Internal conflict & $\begin{array}{l}\text { Armed conflict between the government of a state and } \\
\text { one or more internal opposition group(s) without } \\
\text { intervention from other states }\end{array}$ & $\begin{array}{l}\text { International Peace } \\
\text { Institute, Oslo (PRIO) }\end{array}$ & Research \\
\hline $\begin{array}{l}\text { International internal } \\
\text { conflict }\end{array}$ & $\begin{array}{l}\text { Armed conflict between the government of a state and } \\
\text { one or more internal opposition group(s) with } \\
\text { intervention from others states (secondary parties) on one } \\
\text { or both sides }\end{array}$ & $\begin{array}{l}\text { International Peace } \\
\text { Institute, Oslo (PRIO) }\end{array}$ & Research \\
\hline $\begin{array}{l}\text { Civil liberties and political } \\
\text { rights }\end{array}$ & $\begin{array}{l}\text { Civil liberties and political rights }=\text { (political rights }+ \\
\text { civil liberties) } / 2 \text {. } \\
\text { For Freedom House, countries whose combined average } \\
\text { for political rights and civil liberties fell between } 1.0 \text { and } \\
3.0 \text { (i.e., } 1.0 \leq \mathrm{avg} \text { pr_cl }<3.0 \text { ) were designated "free"; } \\
\text { between } 3.0 \text { and } 5.5 \text { (i.e., } 3.0 \leq \text { avg_pr_cl }<5.5 \text { ) "partly } \\
\text { free"; and between } 5.5 \text { and } 7.0 \text { (i.e., } 5.5 \leq \mathrm{avg} \text { pr_cl } \leq 7.0 \text { ) } \\
\text { "not free" }\end{array}$ & Freedom House & \\
\hline
\end{tabular}


Appendix C: Number of conflicts per year observed

\begin{tabular}{|c|c|c|c|c|c|c|c|}
\hline \multirow[b]{2}{*}{ Country } & \multicolumn{6}{|c|}{ Number of conflicts per period observed } & \multirow{2}{*}{$\begin{array}{l}\text { Total for } \\
\text { period } \\
\text { observed }\end{array}$} \\
\hline & $\mathbf{0}$ & 1 & 2 & 3 & 4 & 5 & \\
\hline ANGOLA & 16 & 40 & 4 & 0 & 0 & 0 & 60 \\
\hline BURKINA FASSO & 56 & 4 & 0 & 0 & 0 & 0 & 60 \\
\hline BURUNDI & 44 & 17 & 0 & 0 & 0 & 0 & 61 \\
\hline BENIN & 61 & 0 & 0 & 0 & 0 & 0 & 61 \\
\hline BOTSWANA & 61 & 0 & 0 & 0 & 0 & 0 & 61 \\
\hline D.R. OF CONGO & 44 & 12 & 5 & 0 & 0 & 0 & 61 \\
\hline CENTRAL AFRICAN R. & 56 & 5 & 0 & 0 & 0 & 0 & 61 \\
\hline CONGO & 55 & 6 & 0 & 0 & 0 & 0 & 61 \\
\hline COTE D'IVOIRE & 58 & 3 & 0 & 0 & 0 & 0 & 61 \\
\hline CAMEROON & 55 & 6 & 0 & 0 & 0 & 0 & 61 \\
\hline ERITREA & 57 & 3 & 0 & 0 & 0 & 0 & 60 \\
\hline ETHIOPIA & 16 & 11 & 15 & 7 & 10 & 1 & 60 \\
\hline GABON & 60 & 1 & 0 & 0 & 0 & 0 & 61 \\
\hline GHANA & 58 & 3 & 0 & 0 & 0 & 0 & 61 \\
\hline GAMBIA & 60 & 1 & 0 & 0 & 0 & 0 & 61 \\
\hline GUINEA & 58 & 2 & 0 & 0 & 0 & 0 & 60 \\
\hline GUINEA EQUATORIAL & 39 & 21 & 0 & 0 & 0 & 0 & 60 \\
\hline GUINEA-BISSAU & 47 & 13 & 0 & 0 & 0 & 0 & 60 \\
\hline KENYA & 55 & 6 & 0 & 0 & 0 & 0 & 61 \\
\hline LIBERIA & 49 & 12 & 0 & 0 & 0 & 0 & 61 \\
\hline LESOTHO & 60 & 1 & 0 & 0 & 0 & 0 & 61 \\
\hline MADAGASCAR & 59 & 2 & 0 & 0 & 0 & 0 & 61 \\
\hline MALI & 57 & 4 & 0 & 0 & 0 & 0 & 61 \\
\hline MAURITANIA & 55 & 6 & 0 & 0 & 0 & 0 & 61 \\
\hline MALAWI & 61 & 0 & 0 & 0 & 0 & 0 & 61 \\
\hline MOZAMBIQUE & 34 & 27 & 0 & 0 & 0 & 0 & 61 \\
\hline NAMIBIA & 61 & 0 & 0 & 0 & 0 & 0 & 61 \\
\hline NIGER & 54 & 6 & 1 & 0 & 0 & 0 & 61 \\
\hline NIGERIA & 52 & 6 & 2 & 0 & 0 & 0 & 60 \\
\hline RWANDA & 50 & 11 & 0 & 0 & 0 & 0 & 61 \\
\hline SUDAN & 24 & 36 & 1 & 0 & 0 & 0 & 61 \\
\hline SIERRA LEONE & 51 & 10 & 0 & 0 & 0 & 0 & 61 \\
\hline SENEGAL & 52 & 9 & 0 & 0 & 0 & 0 & 61 \\
\hline SOMALIA & 40 & 20 & 0 & 0 & 0 & 0 & 60 \\
\hline SAO-TOME \& PRINCIPE & 60 & 0 & 0 & 0 & 0 & 0 & 60 \\
\hline SWAZILAND & 61 & 0 & 0 & 0 & 0 & 0 & 61 \\
\hline CHAD & 26 & 32 & 0 & 1 & 1 & 0 & 60 \\
\hline
\end{tabular}




\begin{tabular}{llllllll} 
TOGO & 61 & 0 & 0 & 0 & 0 & 0 & 61 \\
\hline TANZANIA & 60 & 1 & 0 & 0 & 0 & 0 & 61 \\
\hline UGANDA & 29 & 31 & 1 & 0 & 0 & 0 & 61 \\
\hline $\begin{array}{l}\text { SOUTH AFRICA } \\
\text { REPUBLIC }\end{array}$ & 38 & 16 & 7 & 0 & 0 & 0 & 61 \\
\hline ZAMBIA & 61 & 0 & 0 & 0 & 0 & 0 & 61 \\
\hline ZIMBABWE & 52 & 9 & 0 & 0 & 0 & 0 & 61 \\
\hline Total & $\mathbf{2 , 1 6 3}$ & $\mathbf{3 9 3}$ & $\mathbf{3 6}$ & $\mathbf{8}$ & $\mathbf{1 1}$ & $\mathbf{1}$ & $\mathbf{2 , 6 1 2}$
\end{tabular}

Source: Prio database

Understanding the table: observed over a period of 60 years, Angola was not in conflict for 16 of those years; 40 times during the period of observation, the country experienced at least one conflict and four times, the country had to face two conflicts in the same year. Of the 60 observed periods, only Ethiopia experienced five conflicts in a single year. Only eight countries have not experienced conflict: Benin, Botswana, Malawi, Namibia, Sao-Tome-andPrincipe, Swaziland, Togo and Zambia. 


\section{References}

Altinok, N., 2004. La Banque mondiale et l'éducation en Afrique subsaharienne. De grandes paroles pour de petites actions? Les cahiers de l’IREDU n ${ }^{\circ} 64$.

Akresh, R., de Walque, D., 2008. Armed conflict and schooling: evidence from the 1994 Rwandan Genocide. HiCN Working Paper 47. University of Sussex, Brighton.

Azam, J.P., 2001. The redistributive state and conflicts in Africa. Journal of Peace Research 38 (4), 429-444.

Bird, L., 2007. Children in crisis: Education rights for children in conflict affected and fragile states. Paper commissioned for the EFA Global Monitoring Report 2008, Education for All by 2015: will we make it? UNESCO, Paris.

Beck, N., 2001. Time-series-cross-sections data: What have we learned in the past few years? Annual Review of Political Science 4, 271-293.

Bengtsson, S-E.L., 2011. Fragile states, fragile concepts: a critical reflection on the terminology of fragility in the field of education in emergencies. In: Paulson, J. (Eds), Education, conflict and development. Oxford studies in comparative education, Symposium Books, Oxford, pp. 33-58.

Brakman, S., Garretsen, H., Schramm, M., 2004. The strategic bombing of German cities during World War II and its impact on city growth. Journal of Economic Geography 4 (2), 201-218.

Bush, K.D., Saltarelli, D., 2000. The two faces of education in ethnic conflict: towards a peacebuilding education for children. Insight 4, Innocenti Research Centre, UNICEF.

Chauvet, L., Collier, P., 2007. L'aide aux États fragiles: quand et comment? In Châtaigner JM., Magro, H. (Eds.), États et sociétés fragiles. Entre conflits, reconstruction et développement. Karthala, Paris, pp.435-451. 
Chen, S., Loayza, N.V., Reynal-Querol, M., 2007. The Aftermath of civil war. World Bank Policy Research Working Paper 4190. World Bank, Washington, DC.

Collier, P., Hoeffler, A., 2002. Aid, policy, and growth in post-conflict societies. World Bank Policy Research Working Paper 2902. World Bank, Washington, DC.

Collier, P., Hoeffler, A., Rohner, D., 2006. Beyond greed and grievance: feasibility and civil war. Centre for the study of African economies, Working Paper Series 2006/10, University of Oxford, Oxford.

Davies, L., 2005. Schools and war: urgent agendas for comparative and international education. Compare 35 (4), 357-371.

Easterly, W., 2009. How the millennium development goals are unfair in Africa. World Development 37 (1), 26-35.

Gleditsch, N.P., Wallensteen, P., Eriksson, M., Sollenberg, M., Strand, H., 2002. Armed conflict 1946-2001: a new dataset. Journal of Peace research 39 (5), 615-637.

Harber, C., 2002. Education, democracy and poverty reduction in Africa. Comparative Education 38 (3), 267-276.

International Displacement Monitoring Centre, 2010. Internal displacement monitoring report: Global Overview of Trends and Developments in 2009. Norwegian Refugee Council, Geneva, Switzerland.

Miguel, E., Roland, G., 2006. The long run impact of bombing Vietnam. National Bureau of Economic Research Working paper 11954. University of California, Berkeley.

Miller-Grandvaux, Y., 2009. Education and fragility: a new framework. Journal of Education for International Development 4 (1). 
Novelli, M., Lopez Cardozo, M., 2008. Conflict, education and the global south. IS Academe Working Paper, University of Amsterdam.

O’Malley, B., 2010. Education under attack. UNESCO, Paris.

Pritchett, L., 2001. Where has all the education gone? World Bank Economic Review 15 (3), 367-391.

Smith, A., Vaux, T., 2003. Education, conflict and development. London: Department of International Development.

Smith, A., 2010. The influence of education on conflict and peace building. Paper commissioned for the EFA Global Monitoring Report 2011, The hidden crisis: armed conflict and education, UNESCO, Paris.

UNESCO, 1998. From war to peace in history books. In UNESCO Education news $\mathrm{n}^{\circ} 11$. UNESCO, Paris.

UNESCO, 2010. Reaching the marginalized. Education for All Global Monitoring Report. UNESCO, Paris.

Weber, A., 2009. Sanctioning, clientelism and politicization: the impact of ethnicity on primary and secondary education in Africa. Center for Comparative and International Studies, Working paper $\mathrm{n}^{\circ} 41$, ETH Zurich and University of Zurich.

World Bank, 2003. Breaking the conflict trap: civil war and development policy. World Bank Policy Research Report. World Bank and Oxford University Press, Washington DC. 